\title{
A CORRELATIONAL STUDY BETWEEN EXTROVERSION PERSONALITY, VOCABULARY MASTERY, AND SPEAKING SKILL
}

\author{
Shelia Anjarani, Abdul Asib, Hefy Sulistyawati \\ English Education Department \\ Teacher Training and Education Faculty \\ Sebelas Maret University of Surakarta
}

Email: shelia.anjarani@gmail.com

\begin{abstract}
The article is aimed at investigating the correlation between extroversion personality and vocabulary mastery toward speaking skill of the fourth semester students of English Education Department, Teacher Training and Education Faculty, Sebelas Maret University in the academic year of 2012/2013; both partially and simultaneously. The method of this study is correlational research. The population of the study is all of the fourth semester students while the sample is 30 students taken by simple random sampling technique. The technique used to analyze the data are simple, multiple correlation, and regression by using microsoft excel. The results of the study show that there is a positive correlation between extroversion personality and vocabulary mastery toward speaking skill both partially and simultaneously. The positive correlation indicates that extroversion personality and vocabulary mastery tend to go up or to go down together with speaking skill.
\end{abstract}

Keywords: correlation, extroversion personality, vocabulary mastery, speaking skill

\section{INTRODUCTION}

Human beings need to associate with one another and communicate with a language to keep their relationship. Clark and Clark (1973: 3) state that language is the main means of human communication. There are two forms of communication; they are verbal and non-verbal communication. Verbal communication means to communicate with words whether oral or written words, while non-verbal means without words. Most of human activities are in the form of verbal communication that uses oral language.

O'Malley (1990: 66, 67) reveals that speaking is an example of a complex cognitive skill that can be differentiated into various hierarchical sub skills, some of which might require controlled processing while others could be processed automatically. Speaking has some aspects like pronunciation, vocabulary, grammar, comprehension and fluency. Some research findings disclose that students who have acquired more vocabularies, they will be more likely to articulate and communicate the message. It means, when students have good vocabulary mastery, they will be good in speaking too.

Vocabulary is a part of language element, so it is impossible to avoid vocabulary in using language. Vocabulary is not merely the knowledge of word meaning, but it also includes the skill to determine the word forms, make the decision to use the right and appropriate words, use the right 
expressions and spell them correctly. It means, vocabulary cannot be separated from language skills. It plays an important role in understanding the language holistically.

Because of the importance of vocabulary in communication, many experts have the same opinion as Nunan says that these days, the consensus of opinion seems to be that the development of rich vocabulary is an important element in acquisition of a second language (1991: 118). It is clear that vocabulary is important and needed for communication and also needed in the acquisition of a second language.

There are many factors that influence people to succeed to learn English, especially to acquire speaking skill. Those can come from either the outside of learners or inside of the learners. One of the problems coming from the inside is lacking of extroversion. Extroversion is one aspect constructing personality which influences second language learning especiall 418 gaining speaking skill.

For building a good communication, people must have a good speaking skill. According to some experts, speaking is a part of reciprocal exchange in which both reception and production play a part (Widdowson, 1978: 59); When someone can express what they want to say clearly, use sufficient and proper vocabulary based on context, and can interact with someone else fluently then it can be defined as speaking (Brindley, 1995: 19). Speaking is an oral activity and interactive process that involves some skills: using grammatical word classes, producing fluent speech, using adequate number of words, accurately assessing how well one's interlocutor is understanding other and producing correct English pronunciation.
Vocabulary cannot be separated from other English language skills. It plays an important role in understanding the language holistically. According to some experts, mastery means complete knowledge, great skill and control (Hornby, 1995: 721); comprehensive knowledge (Swanel, 1992: 656)

From the explanation above it can be concluded that vocabulary mastery means the ability to have an understanding or knowledge about the words and its meaning based on some elements like meaning relationship (synonyms, antonyms, and translation), word formation, grammar, collocation and form (pronunciation and spelling).

When psychologists use the term of personality, they are referring to the observation that people display a certain degree of consistency and structure in the ways that they experience and interact with the world (Compas and Gotlib, 2002: 216). It means personality makes people do something in a degree of consistency. Basic dimension of personality involves whether people tend to be unsociable, quiet, and passive (introvert) or sociable, outgoing, and active (extrovert) (Pervin and John, 1970: 234). In addition, they state that the basic difference between extrovert and introvert lies on biological side that is from reticular activated system on the brain.

Eysenck (1963) divided extroversion into seven indicators, activity, sociability, risk taking, impulsiveness, expressiveness, reflectiveness, and responsibility. Extroversion personality as interest in or behavior directed toward others or one's environment rather than oneself. It is the behavior which is influenced by the environment to involve in social group. It is normally characterized by activity, 
sociability, risk taking, impulsiveness, expressiveness, reflectiveness, and responsibility.

\section{RESEARCH METHODS}

The research methodology used in this study is a correlational method. Correlational method is a method whose goal is to describe the relation between two or more events or characteristics (Hallonen and Santrock, 1999: 20), correlations are statistical relationships based on quantitative measures on two or more parameters (While Allison, 1996: 16). This research is one of quantitative research which measure on two or more variables. The reason of choosing this method is the researcher wants to know the level of correlation between two or more variables based on statistic quantitative in correlational coefficient.

There are two kinds of variable in this study, namely dependent variable and independent variable. The dependent variable in this study is speaking skill (Y), while the independent variables are extroversion personality $\left(\mathrm{X}_{1}\right)$ and vocabulary mastery $\left(\mathrm{X}_{2}\right)$. This research explores whether there is a positive correlation between extroversion personality $\left(\mathrm{X}_{1}\right)$ and speaking skill (Y); there is a positive correlation between vocabulary mastery $\left(\mathrm{X}_{2}\right)$ and speaking skill $(\mathrm{Y})$; and there is positive correlation between extroversion personality $\left(\mathrm{X}_{1}\right)$ and vocabulary mastery $\left(\mathrm{X}_{2}\right)$ simultaneously toward speaking skill (Y).

This research was carried out at the English Education Department, Teacher Training and Education Faculty Sebelas Maret University in April to June 2013, to the fourth semester students of English Education Department in the academic year of $2012 / 2013$. The sample of the study is 30 students taken by random sampling technique.

The data were collected by using test and questionnaire. The test was used to collect vocabulary mastery data (in the form of multiple choice test which consists of 40 items) and speaking skill, while the questionnaire was used to collect the data of extroversion personality (which consists of 40 items having four alternatives positive and negative items.

In this study, the validity and the reliability of all items of each instrument above have been tried out. The validity test is using Product Moment Formula and the reliability test is using Kuder-Richardson for multiple choice instrument (the discrete score) and Alpha Croanbach for questionnaire instrument (continuum score).

The technique used to analyze the data was Linear Regression Analysis Statistic by using microsoft excel. The researcher tested the hypothesis using Product Moment and Multiple Linear Regression Formula. Product Moment Formula is used to describe the strength of relationship between two variables (single correlation), while Multiple Linear Regression is used to describe the strength between several independents variables and one dependent variable (multiple correlation). Before entering Linear Regression Analysis, there is major prerequirement analysis for the data. They are normality test, homogeneity test, linearity and significance test.

\section{RESEARCH FINDINGS AND DISCUSSIONS}

Based on the result of the normality test, it can be concluded that Lo (0.067) is lower than Lt (0.161) for extroversion personality, Lo (0.104) is lower than Lt 
(0.161) for vocabulary mastery, Lo $(0.125)$ is lower than Lt (0.161) for speaking skill. Therefore, the data of extroversion personality, vocabulary mastery, and speaking skill are in normal distribution.

Accepting or rejecting is based on: (1) if $\chi^{2_{\mathrm{o}}}<\chi^{2} \mathrm{t}, \mathrm{H}_{\mathrm{o}}$ is accepted (homogeneous); (2) if $\chi^{2_{o}} \geq \chi^{2} t, \mathrm{H}_{\mathrm{o}}$ is rejected (not homogeneous). Because Chi-Square value is lower than ChiSquare table, so the variant data are homogeneous.

The first hypothesis test reveals that the computation of analysis regression $\mathrm{X}_{1}$ and $\mathrm{Y}$, the coefficient of $\mathrm{a}=41.67$, and $\mathrm{b}=$ 0.40 ; so, the equation of regression is $\widehat{Y}=$ $41.67+0.40 \mathrm{X}_{1}$. The significance of regression is found that $\mathrm{F}_{\mathrm{O}}=6.37$, and $\mathrm{Ft}_{\mathrm{t}}$ $=4.2$ in the level of significance $\alpha=0.05$ and degree of freedom ( $\mathrm{df}=1: 28)$. Because, $\mathrm{F}_{\mathrm{O}}>\mathrm{Ft}_{\text {, }}$, the regression of $\mathrm{X} 1$ and $\mathrm{Y}$ is significant. So, the equation of $\widehat{Y}=41.67+$ $0.40 \mathrm{X}_{1}$ is linear and significant. Because the equation is linear and significant, it can be used to predict the correlation between extroversion personality (X1) and speaking skill (Y); it shows that the mean of speaking skill (Y) would increase 0.40 if the extroversion personality (X1) was increased one score in the constant score of 41.67 .

From the single correlation computation of $\mathrm{X}_{1}$ and $\mathrm{Y}$, the coefficient of correlation is $r_{x} l y=0.43$. Then, this value is compared to r-table at the significance level of $5 \%$ for $\mathrm{N}=30$, it is 0.361 . It means that $r_{x} 1 y$ is higher than rt. It means that the correlation is significant; so, there is a positive correlation between extroversion personality (X1) and speaking skill (Y). The effective contribution of extroversion personality toward speaking skill was $14.83 \%$; it means that $14.83 \%$ of speaking skill is influenced by extroversion personality factor.

Ali and Bano (2012: 260) state that extroverts, as a rule, tend to seek out people to interact with. It means, extroverts bring the same characteristics in their language learning, purposely seeking out individuals to practice their speaking with. The personality variable that has received most attention in second language acquisition research is extroversion. Some researchers have claimed that extroverts are better language learners (2006: 213-236) because of their willingness to speak out and their greater desire to communicate. The more extrovert they are, the better their speaking skill will be. Based on Western Nevada College (2013), extroverts tend to focus on the outer world of people, things, activity, and are energized by interaction with others. They love to talk and socialize. That is why extrovert types learn best by speaking and physically engaging the environment.

The second hypothesis test reveals that the computation of analysis regression $\mathrm{X}_{2}$ and $\mathrm{Y}$, it is found that coefficient of $\mathrm{a}=$ 63.48 , and $b=0.16$; so, the equation of regression is $\widehat{Y}=63.48+0.16 \mathrm{X}_{2}$. The significance of regression is found that $\mathrm{F}_{\mathrm{O}}=$ 5.51, and $\mathrm{Ft}_{\mathrm{t}}=4.2$ in the level of significance $\alpha=0.05$ and degree of freedom $(\mathrm{df}=1: 28)$. Because $\mathrm{F}_{\mathrm{O}}$ is higher than $\mathrm{Ft}_{\mathrm{t}}\left(\mathrm{F}_{\mathrm{O}}>\mathrm{Ft}\right)$ so the regression of $\mathrm{X}_{2}$ and $\mathrm{Y}$ is significant. So, the equation of $\widehat{\mathrm{Y}}$ $=63.48+0.16 \mathrm{X}_{2} \quad$ is linear and significant. Because the equation is linear and significant, it can be used to predict the correlation between vocabulary mastery (X2) and speaking skill (Y); it shows that the mean of speaking skill (Y) 
would increase 0.16 if the vocabulary mastery (X2) was increased one score in the constant score of 63.48 .

From the single correlation computation of $\mathrm{X}_{2}$ and $\mathrm{Y}$, the coefficient of correlation is $\left.r_{x} 2 y=0.41\right)$. Then, this value is compared to r-table at the significance level of $5 \%$ for $\mathrm{N}=30$, it is 0.361 . It means that $r_{x} 2 y$ is higher than $r$. It means that the correlation is significant; so, there is a positive correlation between vocabulary mastery $\left(\mathrm{X}_{2}\right)$ and speaking skill (Y). The effective contribution of vocabulary mastery toward speaking skill was $12.36 \%$, it means that $12.36 \%$ of speaking skill is influenced by vocabulary mastery factor.

Nunan (1998: 117) states that the acquisition of an adequate vocabulary is essential for successful second language use because without an extensive vocabulary we will be unable to use the structures and functions we may have learned for communication or speaking. Because vocabulary is central of language in which it is the component of any language and the success in learning language can be proved by the success in mastering vocabulary.

The third hypothesis test reveals that from the computation of multiple regression, it is found that the coefficient of $\mathrm{a} 0, \mathrm{a} 1$, and a2 are $39.91 ; 0.32$; and 0.12 . Therefore, the multiple regression equation of $\mathrm{Y}$ on $\mathrm{X}_{1}$ and $\mathrm{X}_{2}$ becomes; $\widehat{\mathrm{Y}}=39.91+$ $0.32 \mathrm{X}_{1}+0.12 \mathrm{X}_{2}$. The testing result of the significance of regression for $F_{O}$ is 5.07. This result is compared to F-table at the significance level of $5 \%$ and degree of freedom ( $\mathrm{df}=2: 27)$ is 3.35. It means that $F_{O}$ (5.07) is higher than $F_{t}(2,27)$ (3.35), so $\mathrm{F}_{\mathrm{O}}$ is significant. It shows that the equation of $\widehat{\mathrm{Y}}=39.91+0.32 \mathrm{X}_{1}+0.12 \mathrm{X}_{2}$ is linear and significant. Because the equation is linear and significant, it can be used to predict the correlation between extroversion personality (X1) and vocabulary mastery $\left(\mathrm{X}_{2}\right)$ and speaking skill $(\mathrm{Y})$; it means that in every one score increase from extroversion personality (X1) together with vocabulary mastery $\left(\mathrm{X}_{2}\right)$ it increases 0.12 of speaking skill (Y) in the constant score of 39.91 , if there was no increase of extroversion personality $\left(\mathrm{X}_{1}=0\right)$ and there was no increase of vocabulary mastery $\left(\mathrm{X}_{2}=0\right)$, it means every student has the mean of speaking skill (Y) 0.12 , it is shown by constant positive value, and it is 39.91 .

From the multiple correlation analysis, it is found that the coefficient of correlation $(\mathrm{Ry} 1,2)$ is 0.5226 and $\left(\mathrm{R}^{2}\right)$ 0.2731 . The significance testing of this coefficient in $F_{O}$ is significant, so $(R y 1,2)=$ 0.5226 is also significant. The effective contribution is $27.19 \%$. It means $27.19 \%$ factors that influence speaking skill come from extroversion personality and vocabulary mastery factor.

Finocchiaro (1974: 2) states that all normal human beings are able to speak and no tribe is found without an oral language. According to Brown (1980: 110), extroversion is a potential and crucial factor in learning a second language, especially in developing speaking skill. Coady and Huckin (1998: 5) state that vocabulary is central to language and critical importance to the typical language learner.

So, extroversion personality and vocabulary mastery are important factors in speaking skill. And the result is positive correlation between extroversion personality 
(X1) and vocabulary mastery (X2) simultaneously toward speaking skill (Y)

\section{CONCLUSION AND SUGGESTION}

From the study, it can be concluded that there is a positive correlation between extroversion personality and vocabulary mastery toward speaking skill, both partially and simultaneously when in every one score increase from extroversion personality $\left(\mathrm{X}_{1}\right)$ together with vocabulary mastery $\left(\mathrm{X}_{2}\right)$ it increases 0.12 of speaking skill $(\mathrm{Y})$ in the constant score of 39.91 , if there was no increase of vocabulary mastery $\left(X_{1}=0\right)$ and there was no increase of vocabulary mastery $\left(X_{2}=0\right)$, it means every student has the mean of speaking skill (Y) 0.12 , it is shown by constant positive value, and it is 39.91 . It means that improvement of extroversion personality and vocabulary mastery will be followed by the improvement of speaking skill. It also means that extroversion personality and vocabulary mastery contribute to their speaking skill; with the effective contribution $27.19 \%$ in which $14.83 \%$ from extroversion personality and $12.36 \%$ from vocabulary mastery.

Considering that extroversion personality and vocabulary mastery contribute to speaking skill, it is useful for the lecturer to understand students' personality types in order to get the best ways of learning, teaching method, and ideal classroom environment.

In order to increase student's vocabulary mastery, lecturer should improve his/her professional skill, especially in English vocabulary mastery. It can be through formal education improvement, upgrading, and training.

\section{BIBLIOGRAPHY}

Ali, Dilshad Akber and Bano, Dilshat. (2012). Personality Types and Reading: A Correlational Study. Pakistan: Institute of Interdisciplinary Business Research.

Alison, Brian. (1998). Research Skills for Students. London: Kogan Page.

Brindley, G. (1995). Assessment and Reporting in Language Learning: Purposes, Problems, and Pitfalls. Plenary presentation at International Conference on Testing and Evaluation in Second Language Education. Hongkong: Hongkong University of Science and Technology.

Brown, Douglas. (1980). Principles or Language Learning and Teaching. New Jersey: Prentice Hall,Inc.

Clark, H. and Clark, Eve V. (1973). Psychology and Language. New York: Harcourt Brice Jovanovich, Inc.

Coady, J and Huckin. (1988). Second Language Acquisition: a Rationale for Pedagogy. New York: Cambridge University Press

Compass, Bruce. and Ian Gotlib. 2002. Introduction to Clinical Psychology. London: Mc Graw-Hill Higher Education.

Finochiaro, M. 1974. English as a Second Language: From Theory to Practice. New York: Regents.

Hallonen, Jane S., and Santrock, John W. (1999). Psychology: Applied and Application, $3^{r d}$. Boston: McGrawHill College. 
Hornby, A.S. (2003). Oxford Advanced Learner's Dictionary of Current English. Oxford: University Press.

O’Malley, J.M. (1990). Learning Strategies in Second Language Acquisition. Cambridge: Cambridge University Press.

Nunan, David. (1991). Language Teaching Methodology. London: Prentice Hall.

Nunan, David. (1998). Language Teaching Methodology: A Textbook for Teachers. New York: Prentice Hall

Pervin, Lawrence A and John, Oliver P. (1970). Personality: Theory and Research. New York: John Wiley and Sons, Inc.

Western Nevada College. (2013). Personality Types and Learning. Retrieved from http://www.wnc.edu/mbti/personalit y_types_and_learning.php accessed September, 9th 2013

Widdowson, H.G. (1996). Teaching Language as Communication. Hongkong: Oxford University Press. 